\title{
Putative Protein FAM47C
}

National Cancer Institute

\section{Source}

National Cancer Institute. Putative Protein FAM47C. NCI Thesaurus. Code C143111.

Putative protein FAM47C (1035 aa, 115 kDa) is encoded by the human FAM47C gene.

This protein has no known function. 